\title{
القاضي عبد الجبار المعتزلي وآراءه في القياس
}

\author{
Muhammad Amar Adly \\ Fakultas Syariah IAIN Sumatera Utara \\ Jl. Willem Iskandar Pasar V Medan Estate, Medan, 20371 \\ e-mail: amaradly73@yahoo.com
}

\begin{abstract}
Abstrak: Pemikiran al-Qâdhî 'Abd al-Jabbâr tentang Qiyâs. selain sebagai tokoh teolog rasional Muktazilah, Al-Qâdhî 'Abd al-Jabbâr memiliki pemikiran di bidang usul fikih seperti tertuang dalam karyanya al-Mughnî fí Abwâb al-Tawhî̀d wa al-Adl. Dalam salah satu pembahasannya ia berbicara tentang kehujjahan qiyas sebagai dalil syara'. Tulisan ini berusaha mengelaborasi pandangan al-Qâdhî tentang kehujjahan qiyas sebagai dalil hukum. Penulis menemukan bahwa 'illat dengan sendirinya memiliki konsekuensi hukum sekalipun tanpa adanya aturan syara'. Pendapat ini berbeda dengan pandangan mayoritas ulama Sunni yang menyatakan bahwa 'illat tidak memberi implikasi hukum, kecuali ada dalil syara' yang menjelaskannya. Sebagai contoh, memabukkan dalam minuman keras sebelum ada syariat pengharaman bukanlah 'illat pengharaman khamr dan 'illat dijatuhkannya hukum hadd kepada peminumnya. Pemikiran al-Qâdhî ini tampaknya diwarnai oleh ajaran Muktazilah yang menjadikan akal sebagai penentu baik dan buruk serta alat bagi kewajiban menjalankan yang kebaikan dan meninggalkan keburukan.
\end{abstract}

\begin{abstract}
Al-Qâdhî 'Abd al-Jabbâr's Thought on Qiyâs. Although widely known as a Mu'tazilite 'ulamâ who support the supremacy of intellect, al-Qâdhî also well verse in the realm of Islamic legal theory as reflected in his al-Mughnîfi Abwâb al-Tawhîd wa al-Adl. In one of his excerpt, he discusses the position of analogy as a base for argument in Islamic law which becomes the focus of this essay. The author maintains that according to al-Qâdhî 'illat or cause by itself has a legal effect even though prior to the existence of God's rules provided for a certain case. Such view is in contrast with those of Sunni majority who argue that Divine revelation is required for 'illat to be legally effective. For example, intoxication in alcoholic drink prior to its divine prohibition is not a cause for its banning nor is it a motive for punishment of the drunken person. Such al-Qâdhî's thought seems to be influenced by his affiliation with Mu'tazilite creed in which intellect is highly admired for it can determine the good from bad thing, and it also function as a means of performing obligation and avoiding the bad things as well.
\end{abstract}

Kata Kunci: Hukum Islam, qiyâs, al-Qâdhî 'Abd al-Jabbâr, ushûl al-fiqh 
MIQOT Vol. XXXVIII No. 2 Juli-Desember 2014

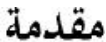

ليس القاضي عبد الخبار رحمه الله أحد أكابر شيوخ الاعتزال في عصرد, وأرفعهم مقاما, وفكرا, وتأليفا فقط, بل هو أيضا من أبرز علماء القرن الرابع والخامس الهجريين, ومد كبار شخصياتما الذي يشار إليه بالبنان.

كان رحمه الله اشتهر بالعلم والفقة واللغة والكالام, حتى قيل: إنه أعلم أهل الأزض. فهو معلم المذهب وشيخه, وفق توفيقا كبيرا في تدعيم المذهب تدعيما كبيرا, بعرضه المسهب لأصوله, ودفاعاته القوية, وتصحيح مساره, وإقصاء الآراء المتطرفة انتي سادت بين بعض رجاله, فساهم بذلك إسواما كبيرا في تقريب المذهب إلى الرأي العام الإسالمي, حتى أضحى التقريب بين المعتزلة, وأهل السنة, أمرا ليس بعيد المنال. لذلك لا غرابة في لقب قاضي القضاة ورئاسة المعتزلة الذي نالهما في عصره. و'قلد اعتى القاضي عبد الجبار بعلم الكالام عناية فائقة, تغوق الفقه. ولنلك لا يعرف له كتاب ين الفقه إلا اختيارات فقهية. أما في أصول الفقه, فقد كان على زأسى من ألف في أصول الفقه من المعتزة, وشاركك بعدة كتب هي الركيزة الأساسية هذا الفن بعد الرسالة للشافعي. ولعلى من أهم مؤلفاته الأصولية وأعظمها, هذا الجزء من كتاب المغني في أبواب التوحيد والعدل المسمى بالشرعيات, إضافة إلى لـ كتب أخرى مثل: العمد, والنهاية, والشرح, والنرس. ومذا البحث سيلقي الضوء - إن شاء الله تعالى - على شخصية القاضي عبد الجبار وجانب من جوانب آراءه الخاصة المتعلقة بالقضايا الأصولية, وهي مسألة القياس كآرائه في حجية القاس ووصف القياس بالدين وتأثير العلة بنفسها في الحكم. ومن هنا فقل جاء موضوع هذا البحث: "القاضي عبد الجبار المعتزلي وآراءه في القياس"

\section{منهج البحث}

ارتكزت بِ منهجي على النقاط التالية:

ا. بدأت في قرأة جميع مئلفات القاضي عبد الجبار خحاصة فيما يتعلق بأصول الفقه، ودى ثم تتبعت آرائه في مسألة القياس.

r. استعنت ببعض الكتب الأصولية لتوضيح مراد القاضي هثل كتاب شتح العهد والمعتهد وآراء المعتزلة الأصولية وغيرها، ومقارنة آرائه بآراء جمهور الأصوليين ككتاب المستصفى, وُلإبماج, وإرشاد الفحول, وروضة الناظر, وأصول السرخسي وغيرها, كما استعنت كذلكك ببعض الكتب الفقهية لتوضيح بعض الفروع التي وزدت في البحث، واستعنت كذلك بمعاجم اللغة وكتب التراجم وغيرها. 
M. Amar Adly:القاضي عبد الجبار المعتز لي وآراءه في القياس r. ثم شرعت في كتابة البحث فجعلت مقدمة لعرض نيذة عن ترجمة القاضي تحرير محل النزاع في القياس،

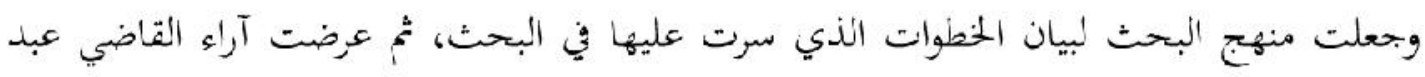

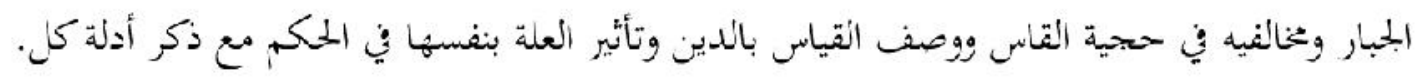
ع. عزوت كل آية كريمة إلى القرآن الككريم.

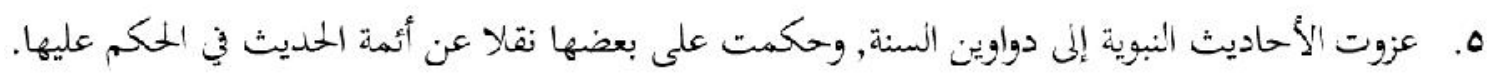

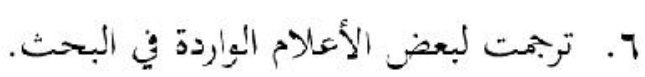

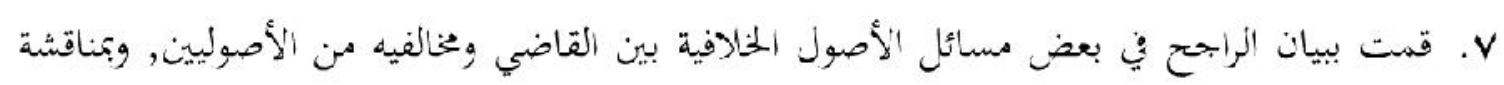
بعض أدلة الرأي المرجوح.

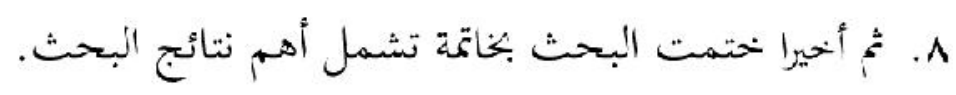

نبذة عن ترجمة القاضي عبد الجبار (1)

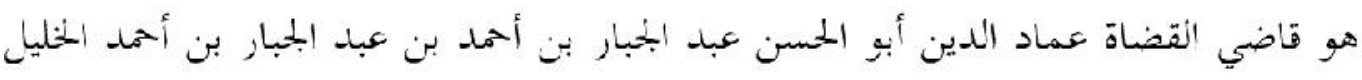

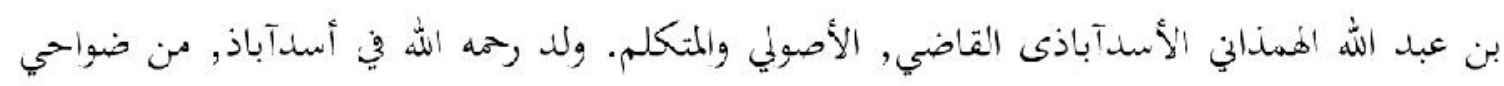

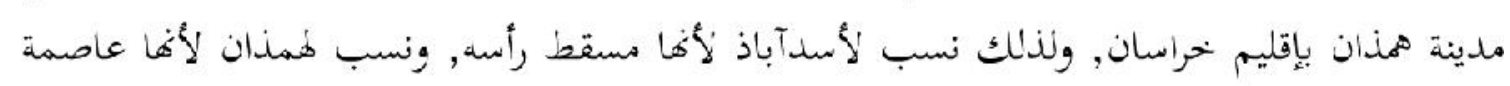

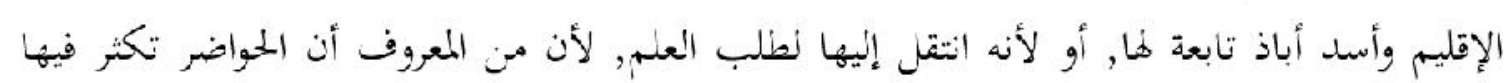
مراكز العنم, وكبار العلماء والشيوخ. وبز تذكر المراجع -التي عثرت عليها- السنة التي ولد فيها, إلا أن ابن الأثير ذكر في كتابه أنه

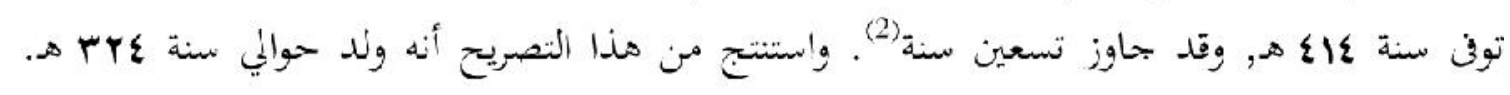

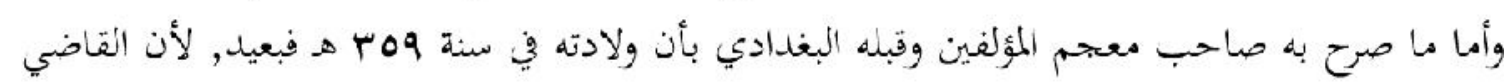

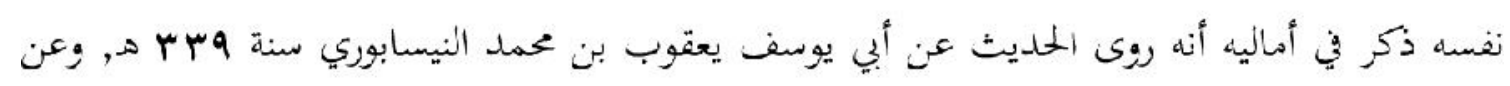

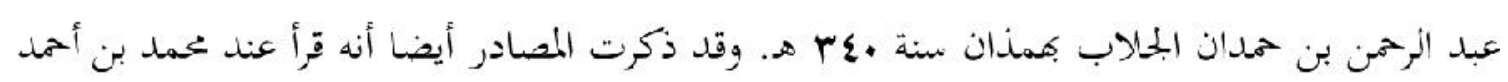

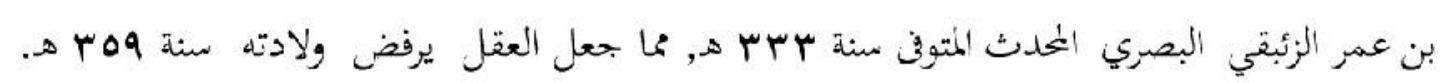

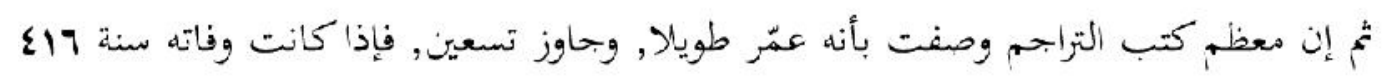

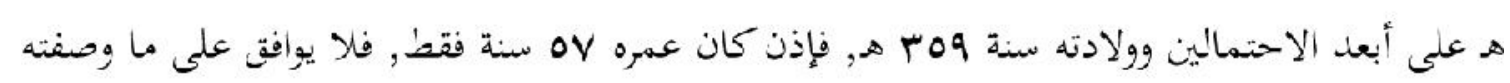

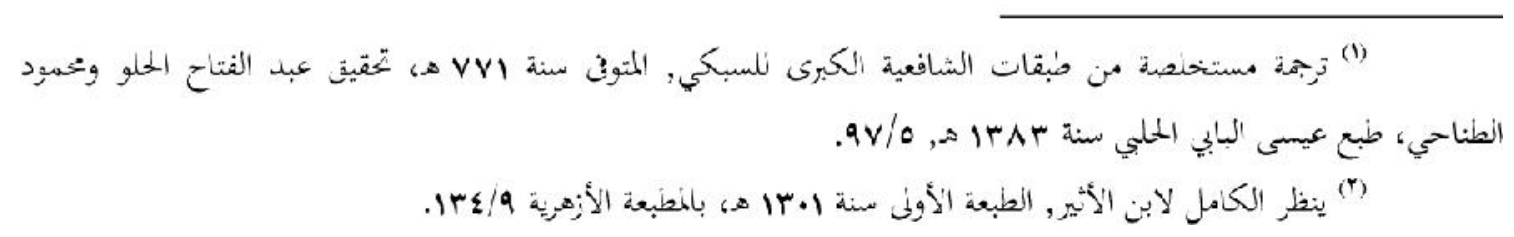


MIQOT Vol. XXXVIII No. 2 Juli-Desember 2014

التراجم. ويستخلص محا ذكرته المراجع أنه ولد في " أسد أباذ ", من أعمال " هذان " بفارس ما بين سنة

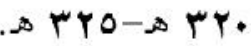

كان القاضي في أول الأمر يذهب في الأصول مذهب الأشعرية، وقد صنف - كما يقول ابن السبكي - تصانيف كثيرة، كما له ذكر شائع بين الأصبوليين، ويذهب في انفروع مذهب الشافعي. ورحل إلى أبي إسحاق بن عياش (3) تلميذ أبي هاشم الجبائي في البحرة, فقرأ عليه مدة, تمح رحل إلى بغداد وأقام عند الشيخ أبي عبد الله البصري (4) مدة مديدة حتى فاق الأقران وخرج فريد دهره كما يذكر ابن المرتضى. وقد ذكر السبكي أنه سمع الحديث من أبي الحسن بن سلمة القطان المتوفى سنة هعب هـ, وعبد الوحمن بن حمدان الجلابب، وعبد الله بن جعفر بن فارس،, والزبير بن عبد الؤحد الأسذآباذي. ويذكر الخافظ البغلدادي بأنه سمع علي ابن إبراهيم بن سلمة التزويني, وعبد الله بن جعفر بن أحمد الأصبهاني,

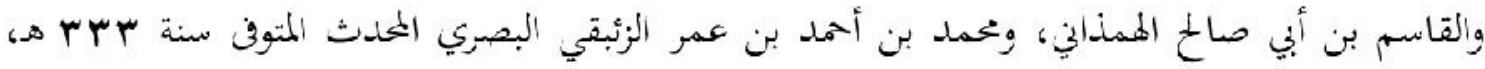

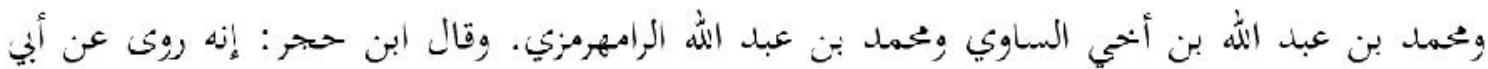
الخسن بن سلمة القطان... ولعله آخر مـ حلثث عنه. وقال أيضا: إنه روى عن عبد الرحمن بن حمدان

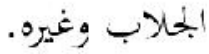

واستدعاه الصاحب (5) إلى الكري بعد سنة ستين وثلاثمائة فولى فيها قضاء القضاة وأعماها، وظلـ فيها يلدرس لطلاب العلم ومريديه حتى أدركته المنية. وكان الصاحب يقول في عبد الجبار: "هو أفضل أهل الأرض ", ومرة يقول: "هو أعلم أهل الأزضر".

ويقول ابن المرتضى: "فلم يعد صوت يعلو على صوتيه المقتدر في مواجهة الخصوم زمخاجة المخحائفين مناظرة وجدلا, فعظم قدره لا بين المعتزلة وحدهم, وإنما بين فرق الزيدية والإمامية, التي بحمع علمائها في حلقته العلمية "(6)".

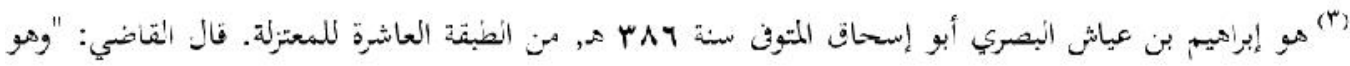

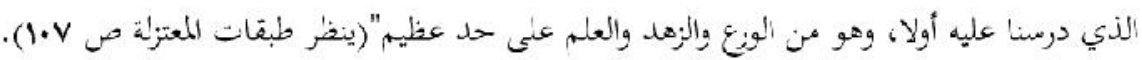

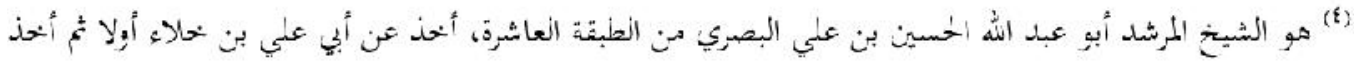

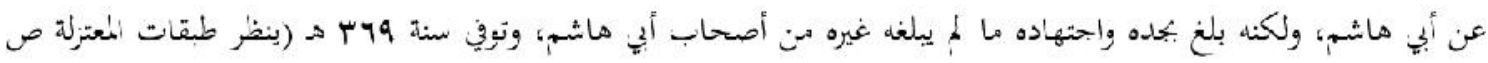
.$(1 \cdot V-1.0$

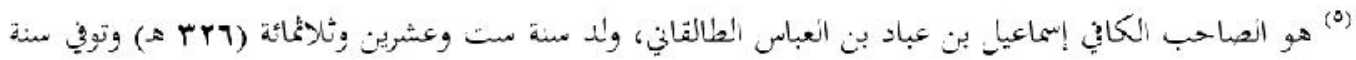

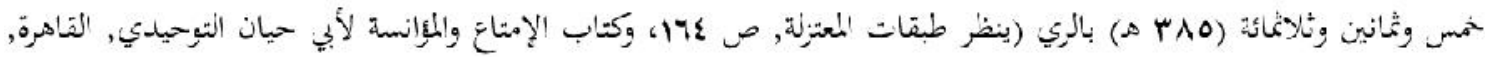

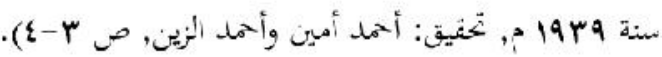

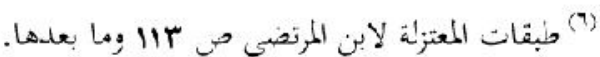


M. Amar Adly:القاضي عبد الجبار المعتزلي وآراءه في القياس

ومما يروى عن التاضي عبد الجبار أنه أراد أن يقرأ فقه أبي حنيفة على أبي عبد الله فقال له: "هذا

علم، كل بحتهد فيه مصيب, وأنا في الحنفية فكن أنت في أصحاب الشافعي". وقد سمع القاضي عبد الجبار النصيحة, وبلغ في الفقه (فقه الشافعي) مبلغا عظيما وله الختيارات. وبالرغم من ذلك فقد وفل أيامه على علم الكالام، وكان يقون في تبرير ذنك: "للفقه أقوام يقومون به طبا لأسباب الدنيا، وعلم الكالام لا غرض فيه سوى العذلـ والتوحيد فليس إلا لله تعالمي". أما مؤلفاته فقال ابن المرتضى, قال الحاكم: يقال إذ له أربع مائة ألف ورقة مما صنف في كل فن.

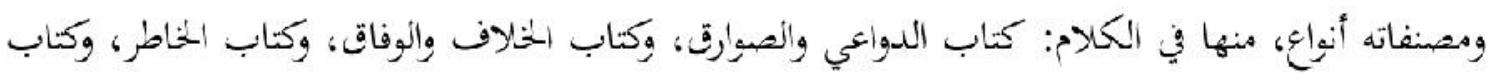
الاعتماد، وكتاب المنع وألتمانع، وكتاب ما يجوز فيه التزايل وها لا يجيوز , إلى غير ذلك محا يكتر تعداده. وأماليه الكثيرة كالمغني، والفعل والفاعل، وكتاب المبسوط، وكتاب المحيط، وكتاب الخكمة والحكيم، وشرح الأصول الخمسة، ومنها نوع في الشروح: كشرح الجاهعين، وشرح الأصول، وشرح المقالات، وشرح الأعراض.

ومنها في أصول الفقه: كالنهاية, والعمد وشرحهه, والمجزي السابع عشر من المني في أبواب الثوحيد والعلن. وموضوعه هو: الشرعيات ويقع في جمى صفحة, وهو كتاب ينقص من أوله حوالي أربعين ورقة مخطوطة, كما ينقص من آخره مقدرا لا يمكن تحديده لم تتفق المرابع لم تذكر تاريخ أيضا على تاريخ وفاته. فها هو ابن الأثير - كما ذكرنا - يقول إنه توفي سنة عاع هـ ولكن ابن حجر يذكر في "السان الميزان" أنه توفي سنة 10ع هـ. ويتفق معه الزركلي في الأعلام والمخطيب البغدادي في تاريخ بغداد والسبكي في طبقات الشافعية الكبرى, ويقول: إنه توفي في ذي القعدة: والذهبي في سير أعالام النبلاء قان: مات في ذي انقعدة سنة خهس عشرة وأربعمائة وهو من أبناء

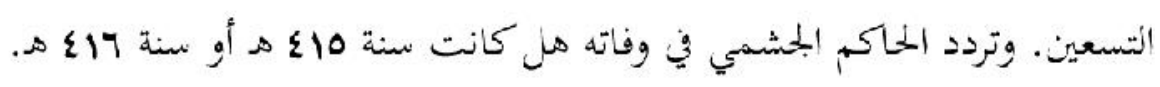

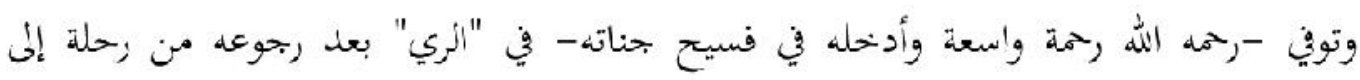
خرسان سنة عاع هـ أو اع هـ. وقد حلد ابن تقي الدين السبكي مكان دفنه، فقال: بأنه دفن في داره.رحمى الله التقاضي, فقد ودع الذنيا بعد جهاد مرير, وكفاح متواصل بلسانه وقلمد, فشهدت له ردهات القصور بالجدل والمناظرات, وسوارى المنساجد بإدارة الحلقات, وخلف ورائه قدره أربع مائة ألف ورقة ما خحلد ذكراه. ولتد ذاق من الدنيا الحلو والمر , فذاق الفقر ومرارته, والغنى وحلاوته, والجلاه والسلطان وعزته, ثخ ذاق بطش السلطان ومكره, غنر الله له ما فرط فيه. 
MIQOT Vol. XXXVIII No. 2 Juli-Desember 2014

\section{حجية القياس عند القاضي عبد الجبار}

اتفق الأصوليون على أن القياس حجة في الأمور الدنيوية(7), كما في الأدوية والأغذية. وكذلك

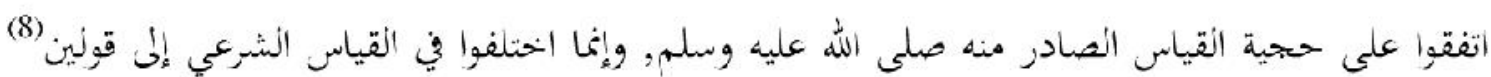
على النتو التالي:

القول الأول: القول بحجية القياس (أن القياس حجة شرعية) وهو رأي القاضي وجمهور الأصوليين.

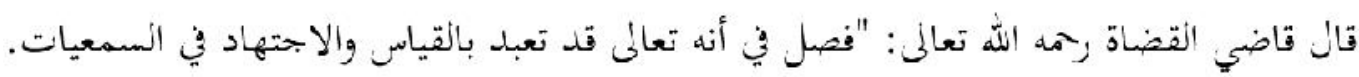

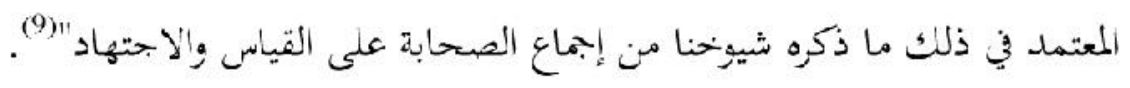

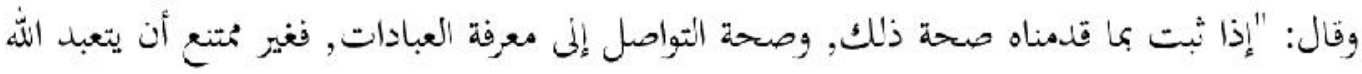

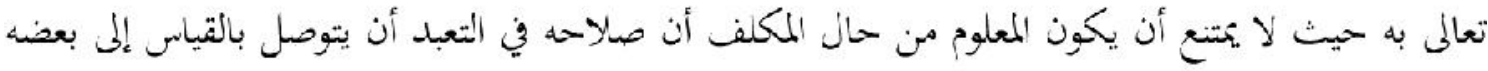

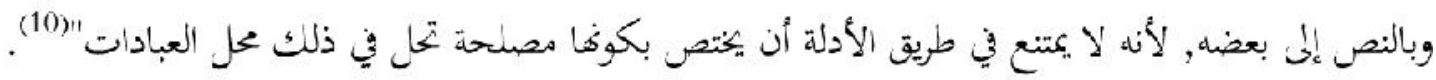

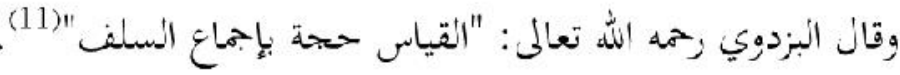

وقال الرازي رممه الله تعالم: "والذي نذهب إليه ومهو قول الجمهور من علماء الصحابة والتابعين

أن القياس حمجة" (12).

وقال الشاشي رحمه الله تعلى : "القياس حجة من حجج الشعع يجب العمل به عند انعلام ما فوقه

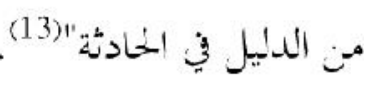

وقال خليل بن كيكلدي العلاثي زممه الله تعانى: "أن القياس حجة شرعية وهو متأخر في الرتبة

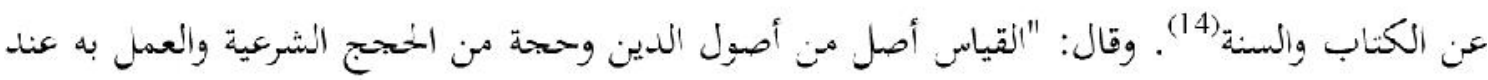

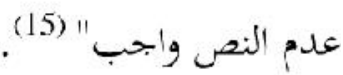

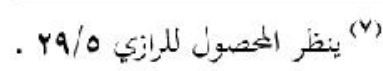

$$
\begin{aligned}
& \text { (A) ينظر إرشاد الفحول ص مبرّ. } \\
& \text { T9Y/IV (9) } \\
& \text { rqr/IV نفس (*) } \\
& \text { (1) }
\end{aligned}
$$

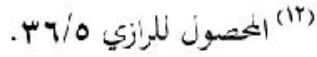

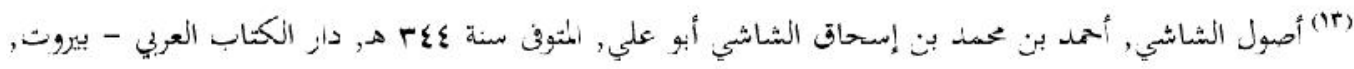

$$
\begin{aligned}
& r+\Lambda, \infty 1 \varepsilon+Y \\
& \text {.29 إجمان الإصابة صن (1) } \\
& \text { Vr_f (10) }
\end{aligned}
$$


القاضي عبد الجبار المعتزلي وآراءه في القياس:M. Amar Adly

وقال محمد بن إسماعيل رحمه الله تعللى في إجابة السائل : "انقياس وهو دليل ثابت الأساس" (16). وقال السرخسي رحمه الله تعالم: "القياس حجة بإجماع السفف من الصحابة"(17). وقال: "انقياس حجة أصلية في تعدية الأحكام لا حجة ضرورية"'(18).

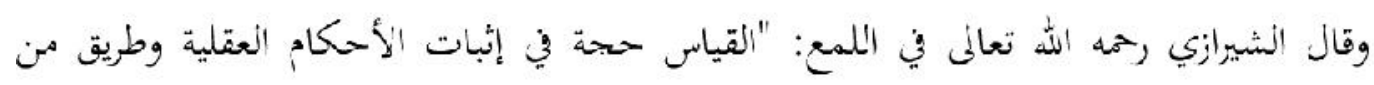
طرقها,....وكذلك هو حجة في الشرعيات, وطريق لمعرفة الأحكام وديليل من أشلتها من جهة الشرع" (19). وقد استدل انقاضي ومن معه بأدلة من الكتاب, والسنة, والإجماع, والمعقبل, وهي كما يلي (20):

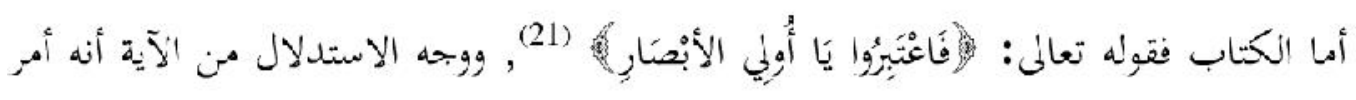
بماهية الاعتبار, والاعتبار مشتق من العبور وهو المرور, يقال: عبرت عليه وعبرت النهر, والمعبر الموضع الذي يعبر عليه, والمعبر السفينة التي يعبر فيها كأفا أداة العبور, والعبرة الدمعة انتي عبرت من الجفن, وعبر

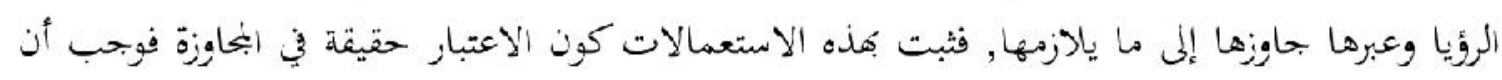

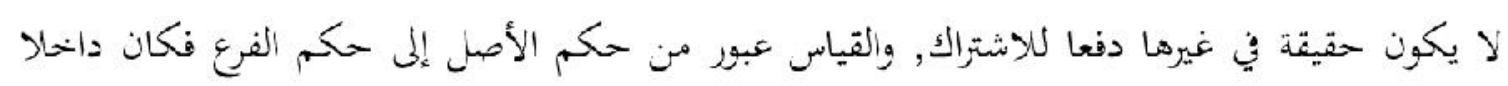
تحت الأمو, لأنه أمر شامل لخميع أنواع الاعتبار ومن جملة أفراده القياسى (22). وأما الحميث فاستدلوا بأحاديث منها:

هوله صلى الله عليه وسلم معاذ بن جبل حين بعثه إلى اليمن قال: (بع تقضي يا معاذ؟) قال: بكتاب

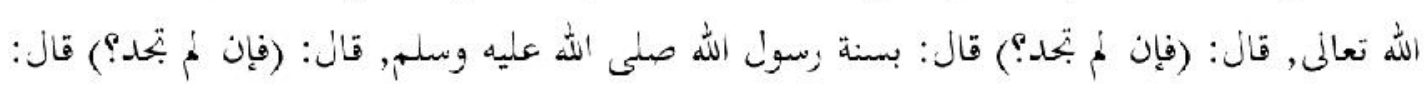
أجتهد برأبي. فصوبه رسول الله صلى الله عليه وسلم وقال: (الحمد لله الذي وفق رسول رسول الله على ما يحب زيرضاه) (23)

$$
\begin{aligned}
& \text { إبحابة السائي صـ (171) }
\end{aligned}
$$

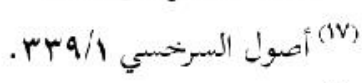

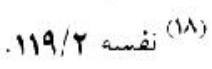

$$
\begin{aligned}
& 98-97 \text { ص } 97 \text { (19) }
\end{aligned}
$$

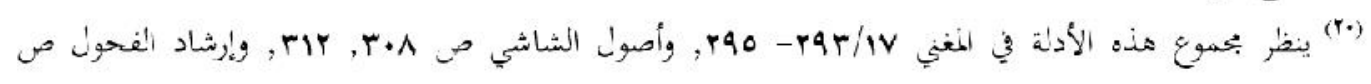

$$
\begin{aligned}
& \text { A }
\end{aligned}
$$

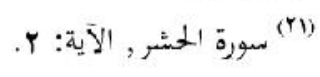

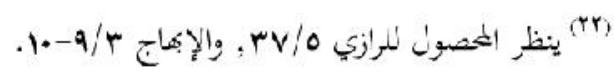

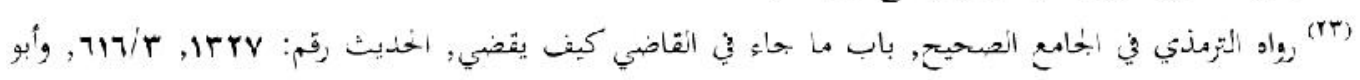

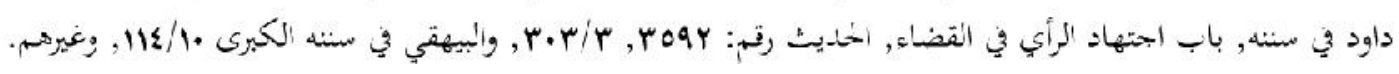


MIQOT Vol. XXXVIII No. 2 Juli-Desember 2014

وما ووي أن امرأة خثعمية أتت إلى رسول الذه صلى الله عليه وسلم فقانت: إن أبي كان شيخا كبيرا أدركه الحج ولا يستمسك على الراحلة فيجزئني أن أحج عنه؟ قال صلى الله عليه وبسم: (أرأيت لو

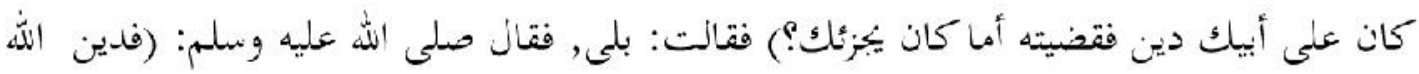
أحقق وأولى). (24) فألمق رسول الله صلى الله عليه وسلم الخج في حقى الشيخ الفاني بالحقبق المالية, وأشار إلى علة مؤثرة في الجواز وهي القضاء, وهذا هو القياسى (25). قال القاضي عبد الجبار في المغني: "قد ثبت أنه صلى الله عليه وسلم في غير قصة, قد نبه الغير عند الند المسألة على طريقة القياس والاجتهاد, نهو ما زوي في خحبر الخثتعمية وغيرها,....ولا يجوز هنه صلى الله عليه وسلم, أن ينبه على هذه الطريقة إلا والمعلوم أن مثلها طريقة صحيحة, ولو تنبه أها تؤدى قبل لصح مع عدم النص, فهذا يقتضي إثبات القياس في الشرعيات" (26). وما زوى عن قيس بن طلق بن علي أنه قال: جاء رجل إلى رسول الله صلى الله عليه وسلم كأنه

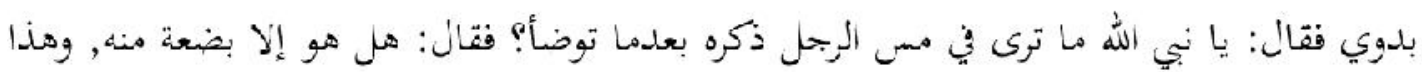
هو القياس (27).

وسئل ابن مسعود عمن تزوج امرأة ولم يسم هلا مهرا, وقل مات عنها زوجها قبل الدخول, فاستمهل

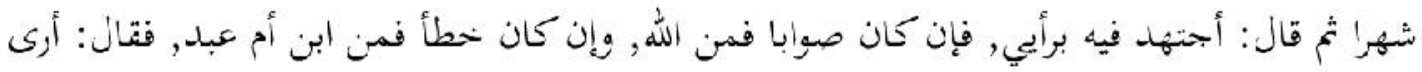
أن لها مهر هثل نسائها لا وكس فيها إن يككن صوابا فمن الله, وإن يكن خعأ فمني ومن الشيطان, والرأي هو القياس (28).

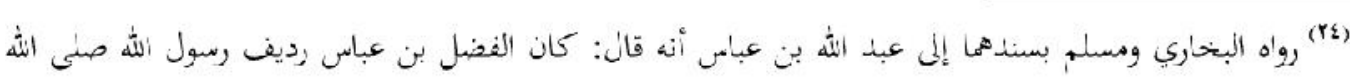

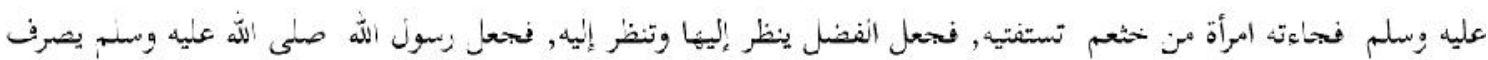

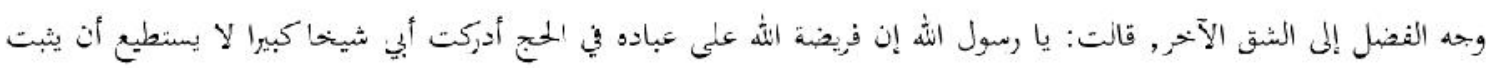

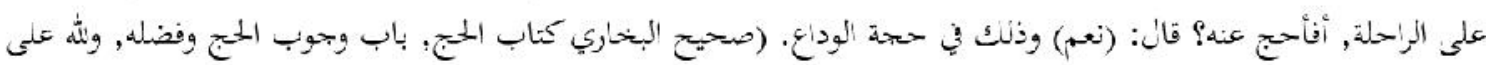

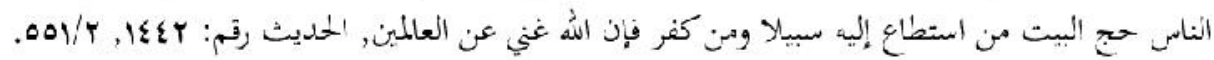

$$
\begin{aligned}
& \text { ro) } \\
& \text { r.ritv المغني (rT) }
\end{aligned}
$$

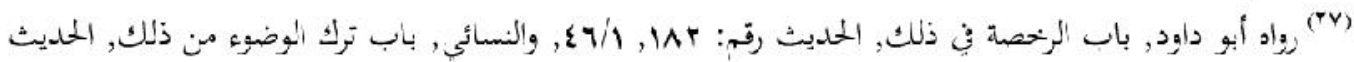

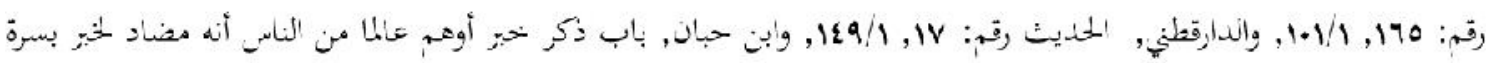

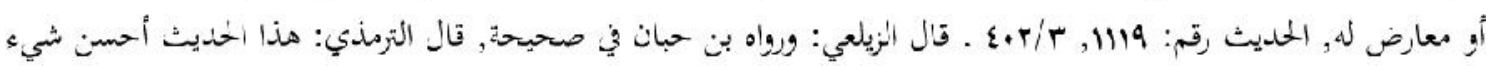

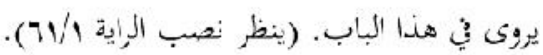

$$
\begin{aligned}
& \text { هنئ (N/) }
\end{aligned}
$$


ومن المعقون: إن ظُ تعليل الحهم في الأصل بعلة توجد في الفرع يزجب ظل الحكم في الفرع, والنقيضان لا يمكن العمل هما ولا انترك لهما والعمل بالرجيع بمنوع فيبقى الراجح. هذا وجه عقلي,

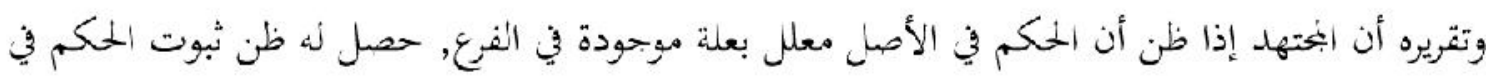
الفرع, والظُن بوجود الشيء يستلزم الوهم بعلدمه لعدم انفكاك كل من الظن أو الوهم عن الآخر, والعمل

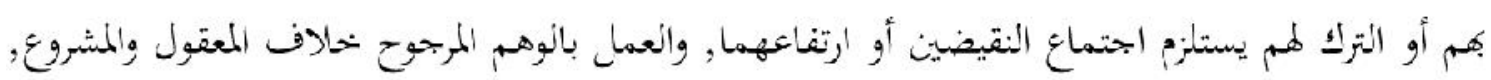

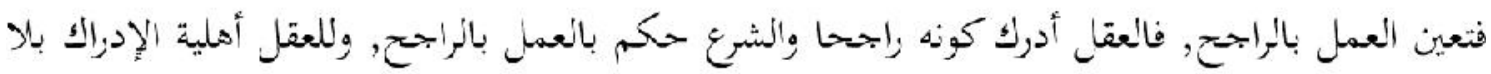
نزاع بين العقلاء (29)

القول الثاني: القول بعلم حجية القياس (أن القياس نيس حجة شرعية). وهذا رأي النظام, وجعفر بن حرب, وجعفر بن حبشه، ومحمد بن عبد الله الإسكاتئ, وداوح الظاهري.

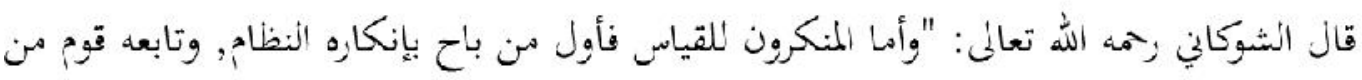
المعتزلة كجعفر بن حرب, وجعفر بن حبشة, ومحمد بن عبد الله الإسكافي, وتابعهم على نفيه في الأحكام داون الغاهري" (30).

واستدل النظام ومدن معه بأدلة من الككتاب, والسنة, والإجماع, والمعقول, وهي كما يلي (31):

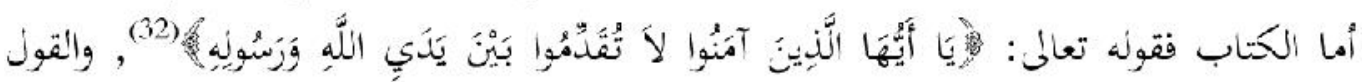
بالقياس تقديم بين يدي الله ورسونه إذ هو قول بغير الكتاب والسنة, وأيضا فالقياس إغا يفيد الظن والظن.

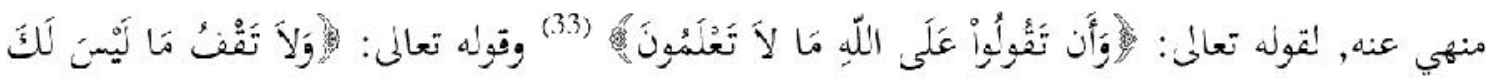

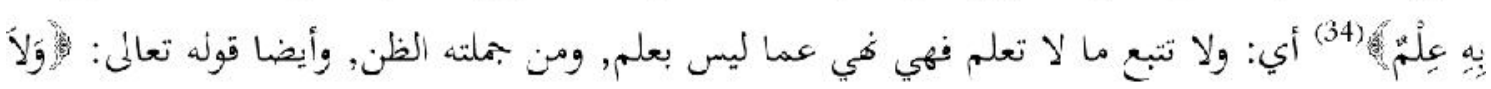

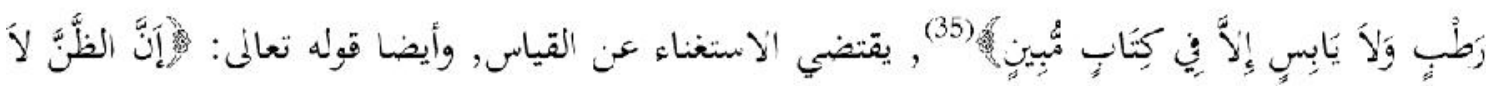

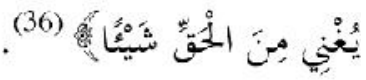

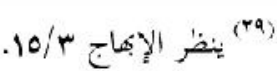

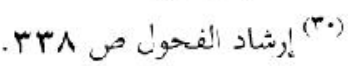

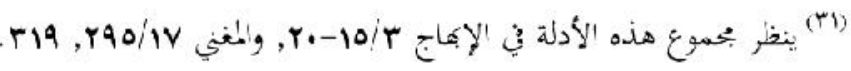

$$
\begin{aligned}
& \text { (rr) } \\
& \text { (r) سوزة البقرة, الآية: } 179 .
\end{aligned}
$$

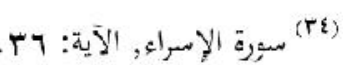

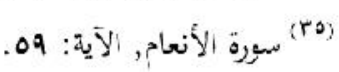

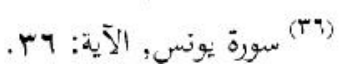


MIQOT Vol. XXXVIII No. 2 Juli-Desember 2014

ومن السنة فقوله صلى الله عليه وسلم: (تعمل هذه ألأمة برهة بالكتاب وبرهة بالسنة وبرهة

بالقياس فإذا فعلوا ذلك فقد ضلونا) (37).

ومن الإجماع: ذم بعضى الصحابة له من غير نكير فكان إجماعا, كما نقل الإمادية من الشيعة

إبماع العترة على أنه لا يجوز العمل بالقياس.

وهن المعتول ها يلي:

أ- أن القياس يؤدي إلى الخلالف والمنازعة, وكل ما كان كذنك فهو منهي عنه, أما كون القياس يؤدي إلى الخلاف فائن القياس مبني على الظن وهور مختف باختلاف القياسين, وأما كونه يؤدي إلى المنازعة

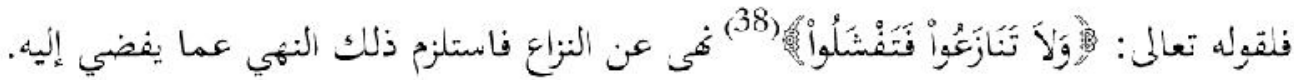
ب- أن الشارغ فصل بين الأزمنة والأمكنة في الشرف, والصلوات في التصر, وجمع بين الماء وانتراب في التطهير, وأوجب التعغف على الحرة الشّهاء دون الأمة الحسناء, وقطع السارق القليل دون غاصب الكثير, وجلد في الزنا وشرط فيه شهادة أربعة دون الكفر , وذلك ينافي القياس. ج- أن مدار شرعنا على الجمهع بين المختففات, كما جمع بين الماء والتراب في استباحة الصمالة بهما مع أن الماء ينظف والتراب بضده, وجعل الخرة الشوهاء تحصن ويكرم النظر إليها دون الجحارية المحسناء, وقطع السارق القليل ما لم ينقص عن ربع دينار دون غاصب الكثير هع أن غاصب الكثير أبنغ في الفحش, لأنه يأخذ المال جهرا على تغلب والسمارق يأخذه سرا على تخوف وأعظم في الأذى لكثرته, وجلد في القذف بالزنا بخلاف القذف بانكفر مع كونه أبلغ, وشرط فيه شهادة أربعة وأكتني في الشهادة على القتيل والكفر باثنين, ورإذا ثبت هذا وجب أن لا يصح القياسى, لأن مبناه على أن الصوزتين لا اشتركا في الحكمة وجب اشتراكهما في الحكم وهو باطل (39). د- وأنه لو جاز أن يتعبد في الأحكام بالقياس لجاز أن يقبح لنا الخبر عن الأمور بالقياس, أو يوجب ذلك

$$
\text { علينا حتى يخبر عت الأمور المنستقبلة قياسا (40). }
$$

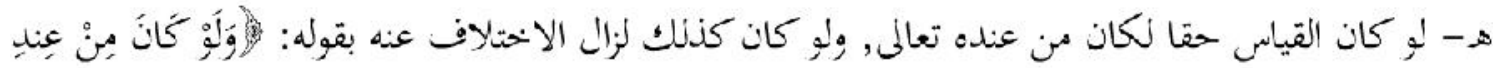

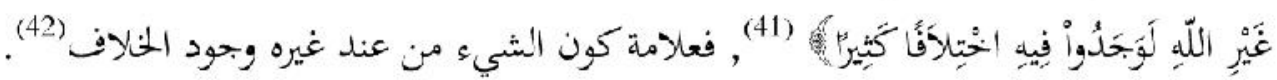

$$
\begin{aligned}
& \text { (rV) }
\end{aligned}
$$

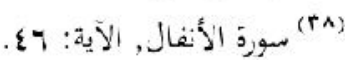

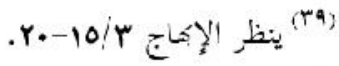

$$
\begin{aligned}
& \text { (8.) }
\end{aligned}
$$

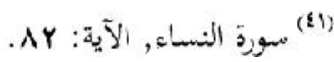




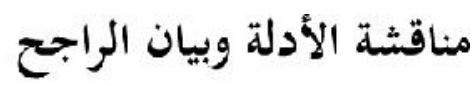

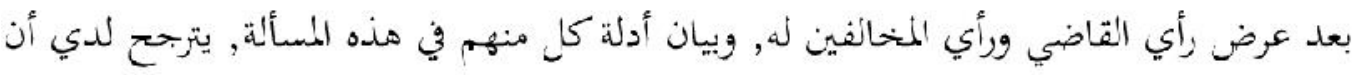

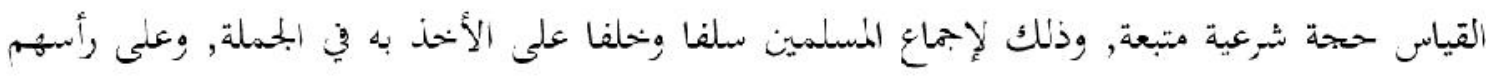

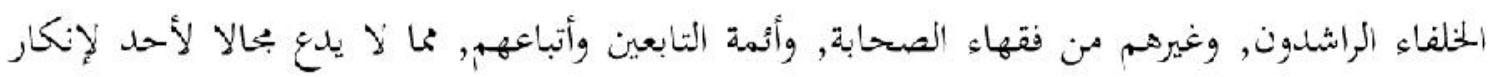
حجيته في بناء الأحكام الشرعية.

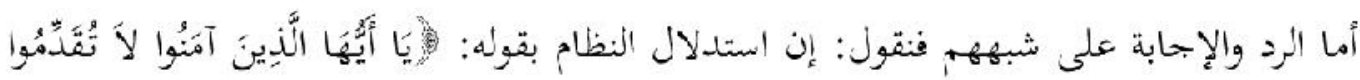

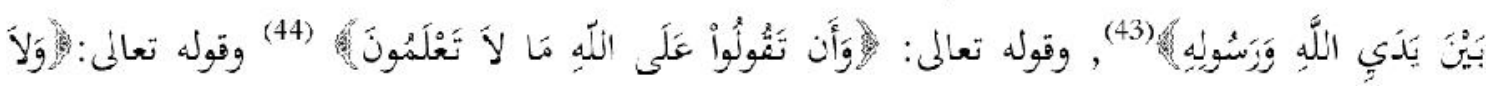

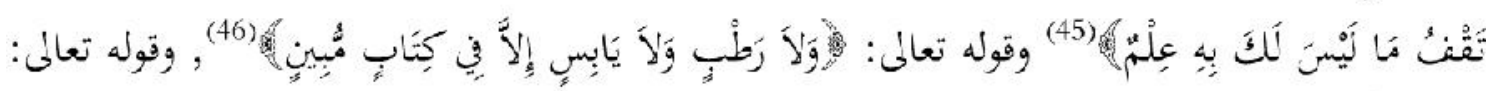

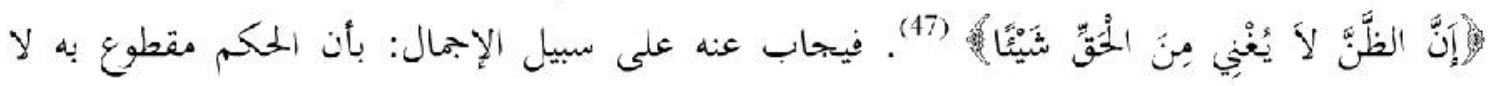

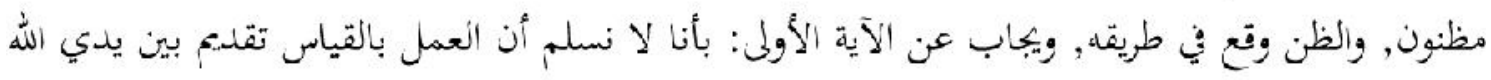

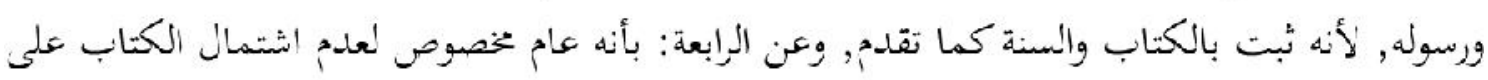

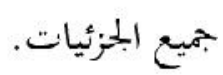

وأما قوله صلى الله عليه وسلم: (تعمل هذه الأمة برهة بالكتاب وبرهة بالسنة وبرهة بالقياس فإذاذ

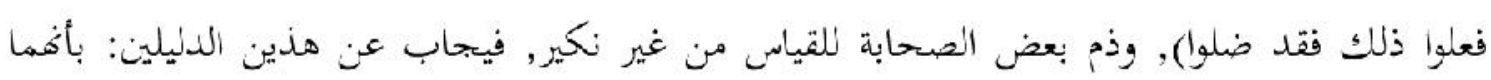

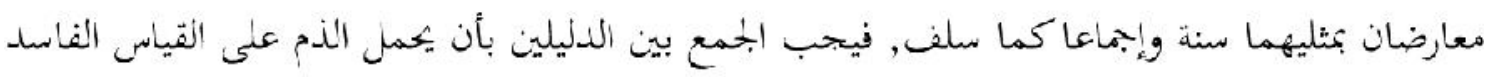

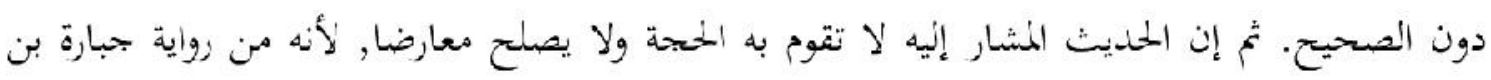

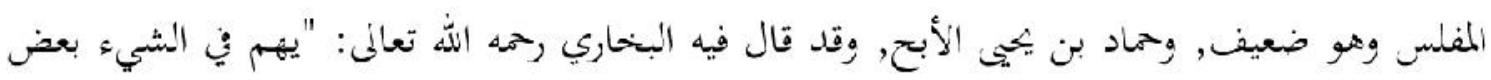

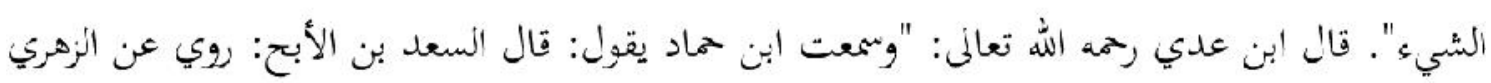

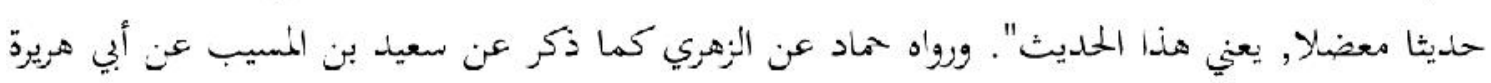

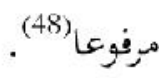

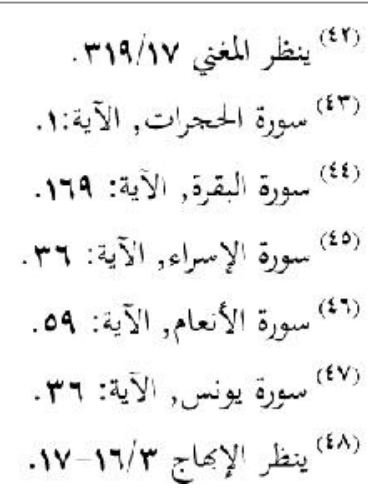


MIQOT Vol. XXXVIII No. 2 Juli-Desember 2014

وأما نقل الإمامية من الشيعة إجماع العترة على أنه لا يجوز العمل بالقياس, فيجاب عنه: بأن

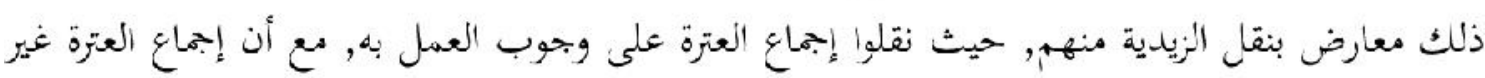
${ }^{(49)}$

وأما قوهم: بأن القيانس يؤدي إلى الحلاف والمنازعة, وكل ما كان كذنلك فهو منهي عنه, أما

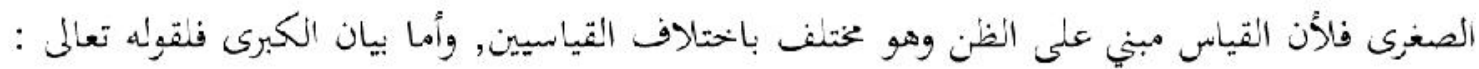

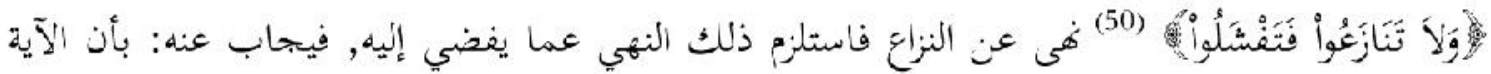

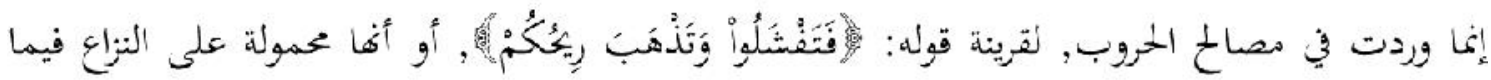

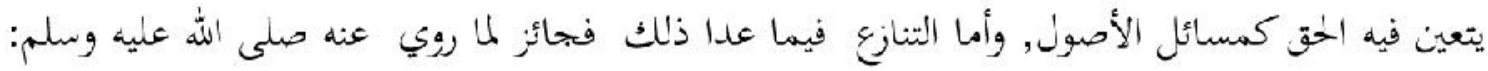
(اخختلاف أمتي رحمة) (51) فيحمل الحديث على ما عدا ذلك (52).

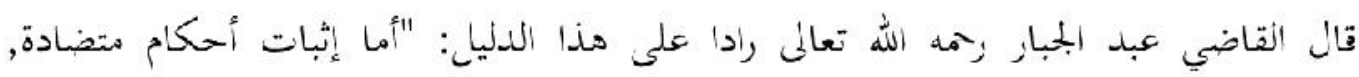

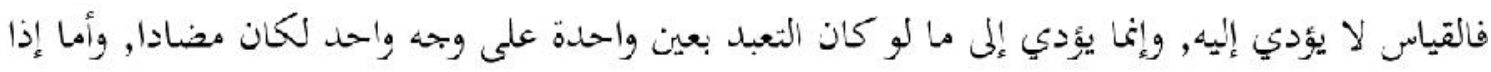

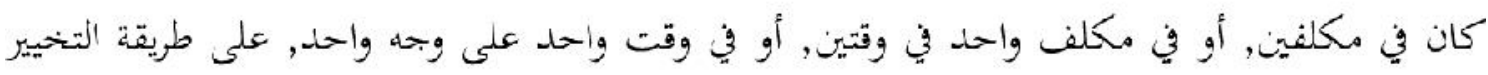

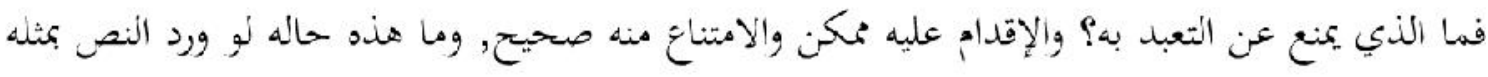

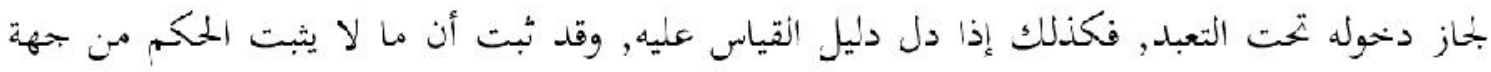

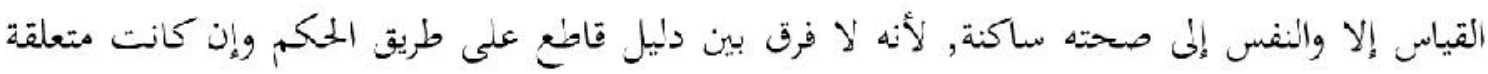
بغالب الظّ, وبين دليل قاطع على غير طريق المكمي" (53).

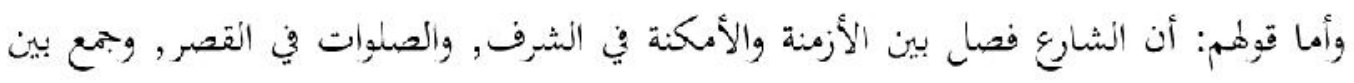

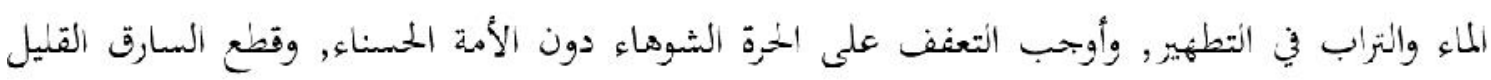

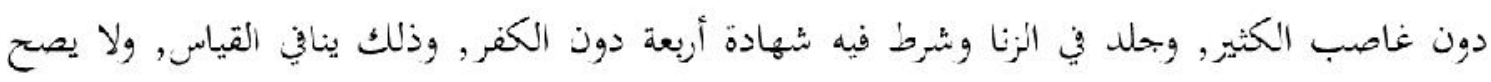

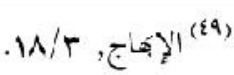

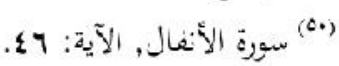

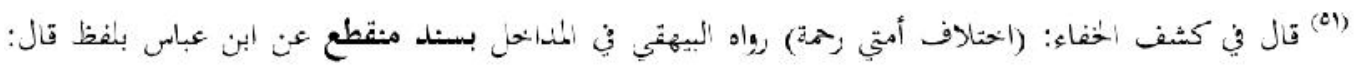

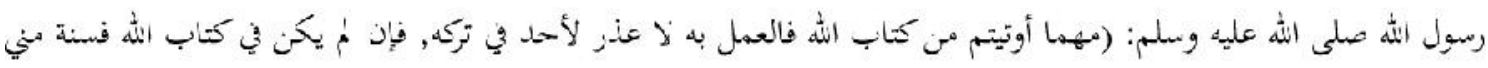

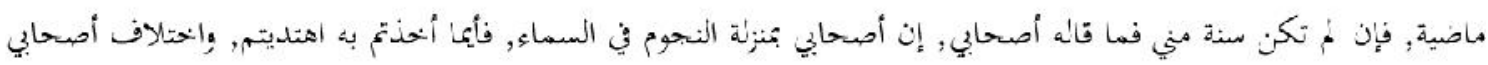

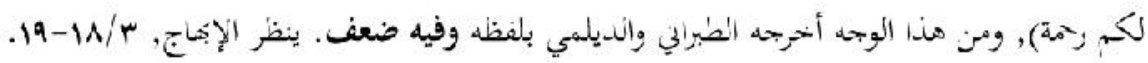

$$
\begin{aligned}
& \text { (or) }
\end{aligned}
$$

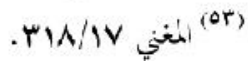


M. Amar Adly:القاضي عبد الجبار المعتز لي وآراءه في القياس

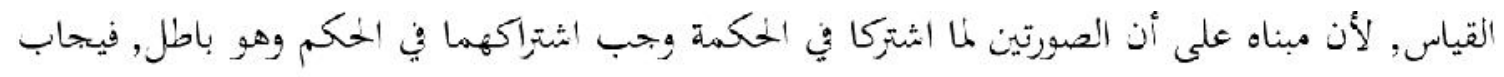

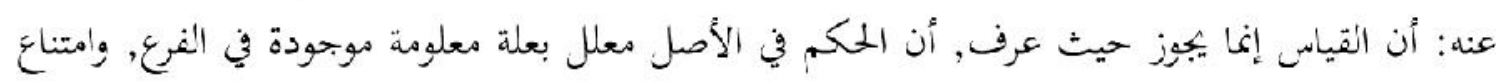

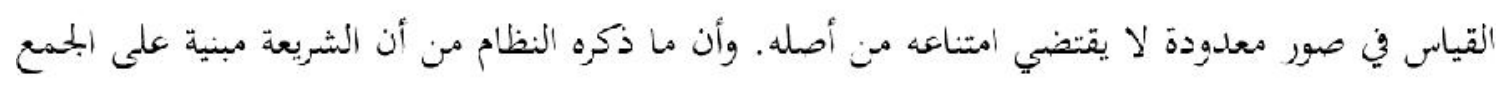

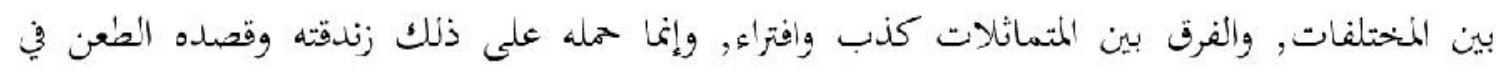

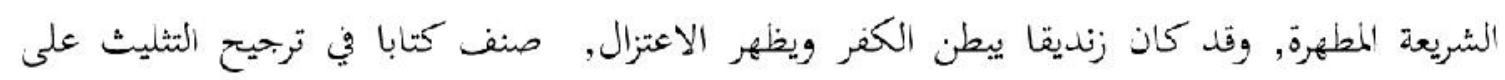

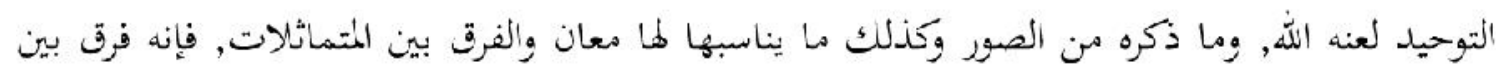

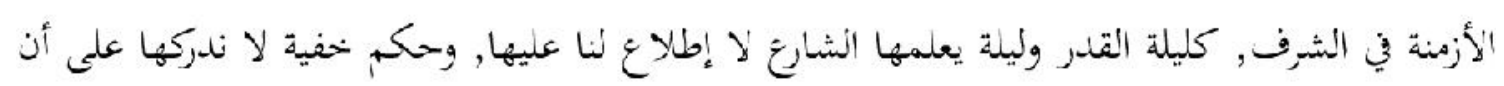
الصوز المذكروة قد ذكرت معانيها (54).

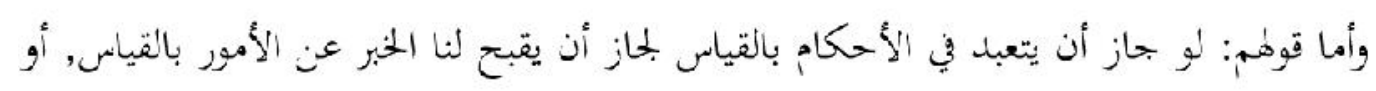

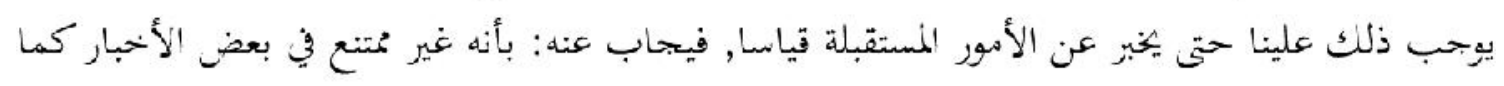

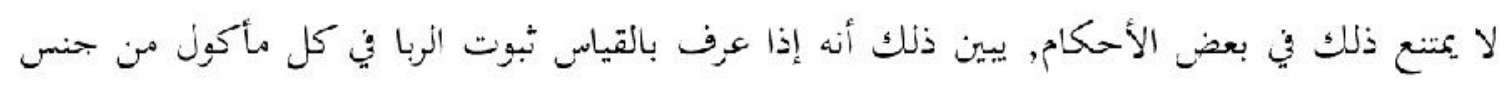

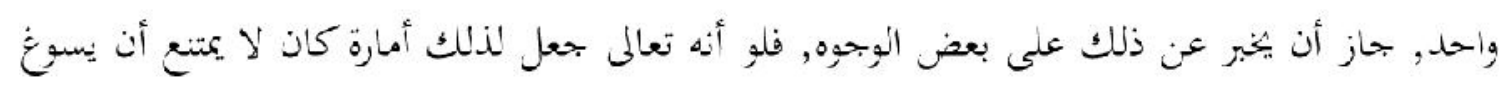

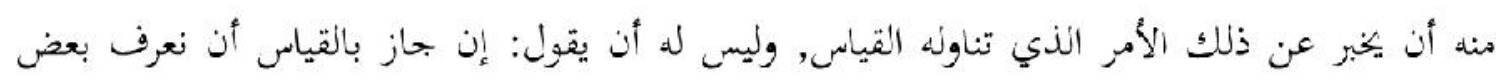

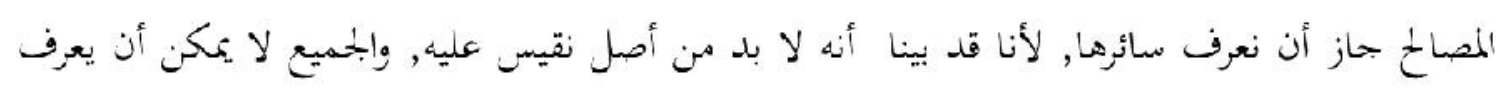
بالقياس هلذه العلة (55).

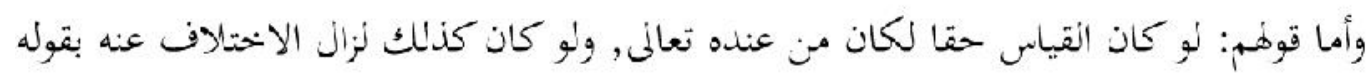

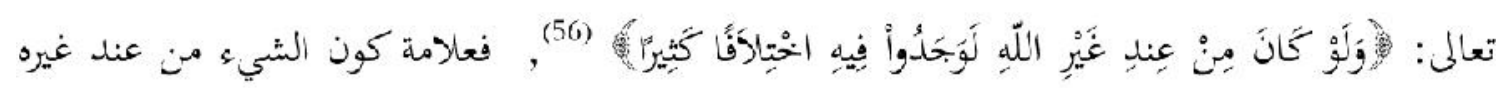

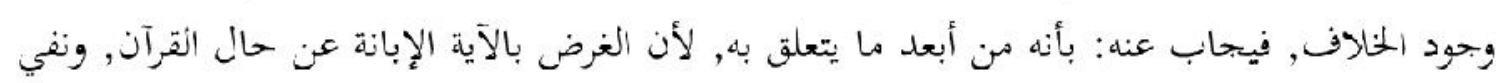

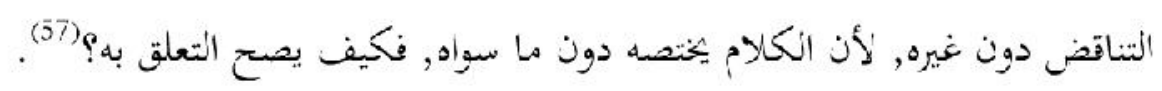

\section{هل يوصف القياس بالدين أم لا ؟}

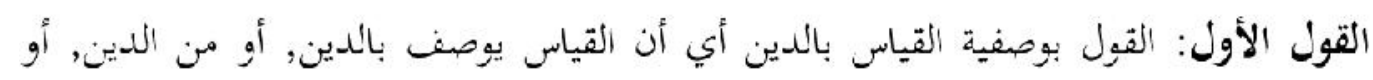
يسمى دينا. وهذا رأي انقاضي عبد الجبار رحمه الله تعالى, ووافقه على هذا الرأي جمهور الأصوليين.

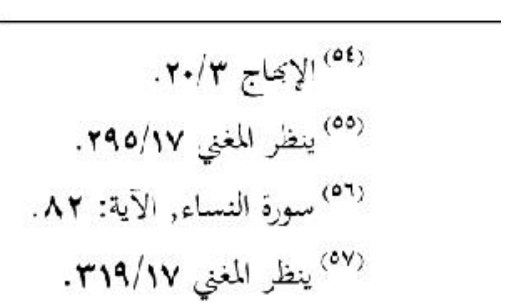


MIQOT Vol. XXXVIII No. 2 Juli-Desember 2014

قال القاضي رحمه الله تعالى: "ولمذه الجملة قلنا في القياس والاجتهاد إفما من الدين" (58). وقال ابن السبكي رحمه اللّ تعالى: "القياس من الندين" (59). وقال أبو الحسين البصري زحمه الله تعالم: "وأما وصفه بأنه دين الله تعلى فلا شبهة فيه, إذا عني بذلك أنه ليس ببدعة" (60).

وقال أبو الخطاب رحمه الله تعالي: "أما من وصفه بأنه دين فلا شبهة فيه, لأن ما تعبدنا اللّ سبحانه وتعالي به فهو دين" (61). واستدل القاضي بأن القياس عبارة عن فعل مخصوص من القياس يتعلق بالأدلة والأمارات، وليس

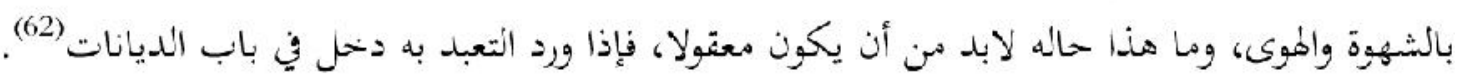
القول الثاني: القول بأن انقياس لا يوصف بالدين, ولا من المدين, ولا يممى دينا. وهذا رأي الشيخ أبي الهذيل رحمه الله. قال أبو الحسين البصري رحمه النه تعانى حكاية عن رأبي أبي الهذيل في المسألة: "إن عني غير ذلك, فعند الشيخ أبي الهذيل رحمه الله أنه لا يطلق عليه ذلك, لأن اسم الدين يقع على ما هو ثابت مستمر "(63). وانتدل على ذلك بأن القياس فعل المكلف, فكيف يكرئ ديلي من الدين وهو فعل القائس؟(64).

\section{مناقشة الأدلة وبيان الراجح}

بعد عرض رأي القاضي ورأي المخالفين له, وبيان أدلة كل منهم في هذه المسألة, يتزجح لدي أن القياس يوصف بالدين, أو من الدين, أو يسمى دينا, كما هو زأي القاضي وجمهور الأصوليين. وذلك لوزود الأمر الشرعي بالتعبد به, وإنعتاد إجماع الأمة في الجملة بمقتضاه, وكل ما كان مأمورا به شرعا فهو من اللدين. أما الجواب على دليله إن القياس فعل المكلف فلا يكون دليلا من الدين لأنه فعل القائس, فنقول: "بأن هذا الرجل ظن أن الدين لا يصح أن يكون من فعل المكلف, ولم يعلم أنه لا يجيوز إلا فعل

$$
\begin{aligned}
& \text { TVN/IV المغني (OA) } \\
& \text { (Oa) }
\end{aligned}
$$

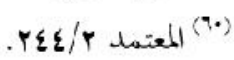

$$
\begin{aligned}
& \text { (") النمويد }
\end{aligned}
$$

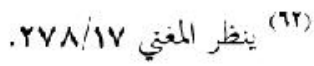

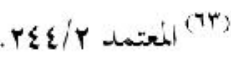

$$
\begin{aligned}
& \text { rVA/IV ينظر المغني }
\end{aligned}
$$


المكلف كما أن العبادة لا تكون إلا فعله, وظن أيضا أنه إذا كان فعلا للمكلف لم يعرف به الحكمي, وهذا.

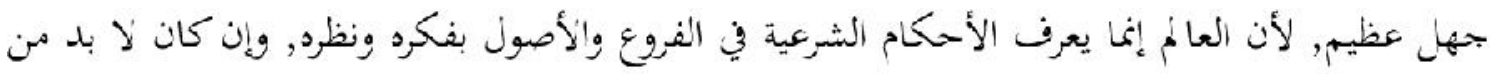

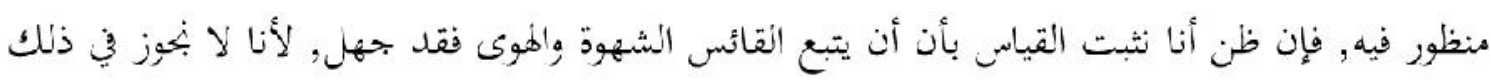

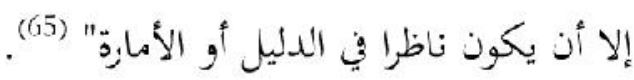

\section{في تأثير العلة بنفسها في الحكم}

القول الأول: يرى القاضي عبد الجمبار رحمه الله تعالى أن العلة مؤثرة بنغسها, بلغة أخرى أخها

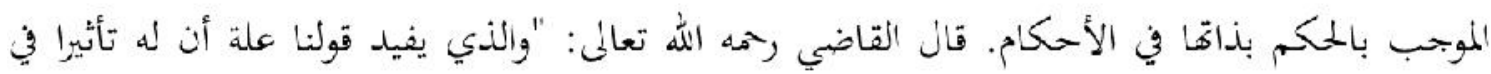

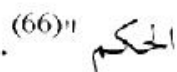

$$
\text { واستدل القاضي بأدلة منها: }
$$

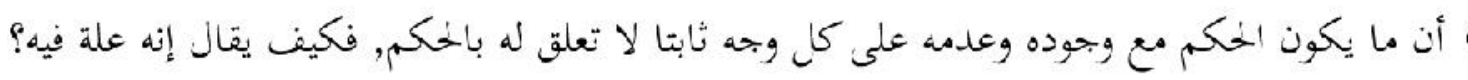

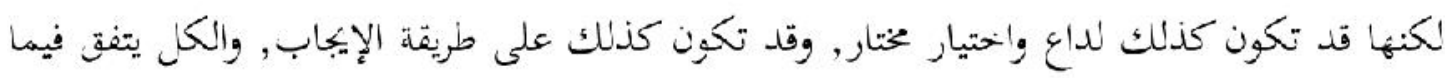

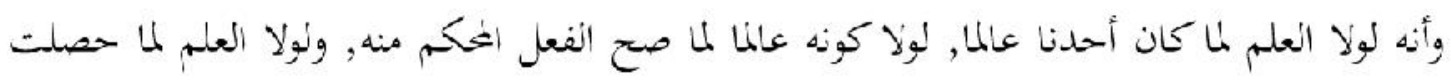

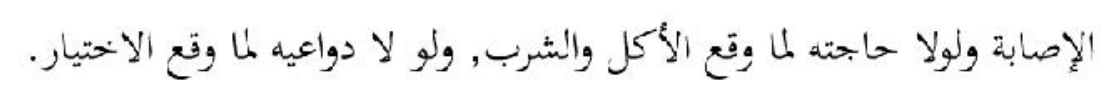

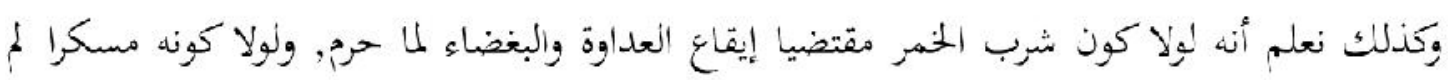

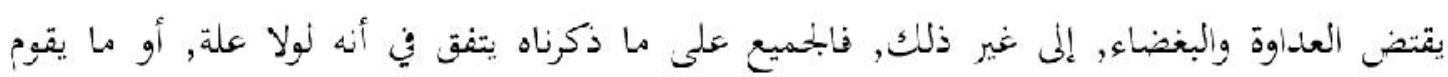

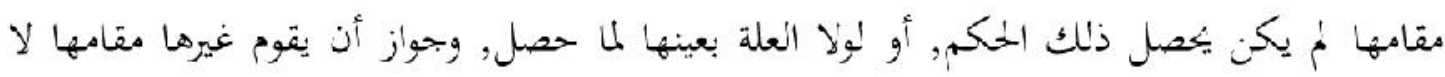

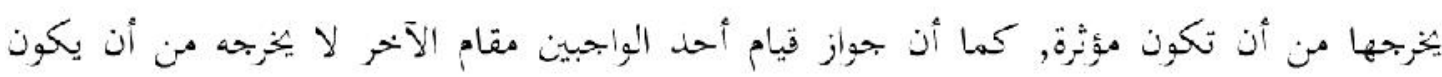

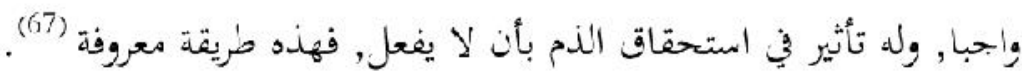

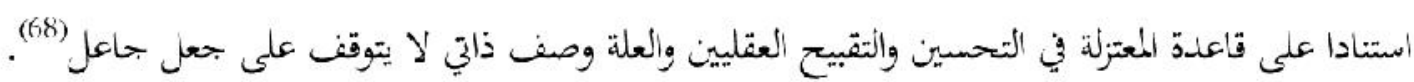

$$
\begin{aligned}
& \text { (10) هذا نص جواب الققاضي عبد الخبار على أبي هذيل.( المغني YVN/IV). } \\
& \text { rno/ir (19) }
\end{aligned}
$$

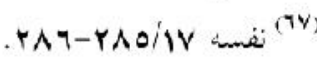

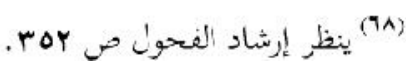


MIQOT Vol. XXXVIII No. 2 Juli-Desember 2014

القول الثاني: القول بعدم تأثير العلة في الحكمم بذاتها, وإنما المؤثر الحقيقي في الحكم هو الشارع وحدد. وهذا رأي جمهور الأصوليين.

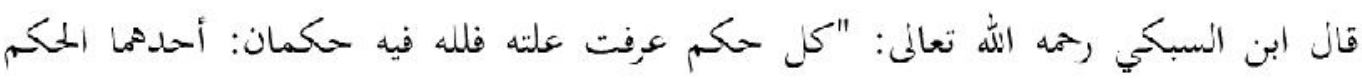
بالسببية, وانختلف الناس في جواز القياس, والثاني الحكمم بالمسبب والقياس عليه جائز باتفاق القايسين.

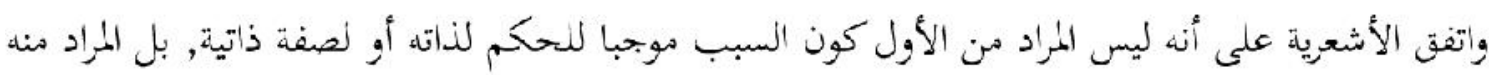

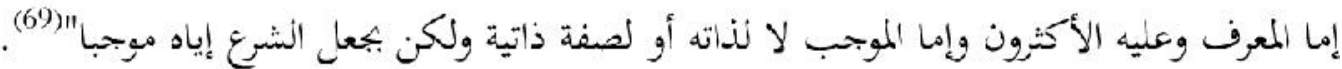

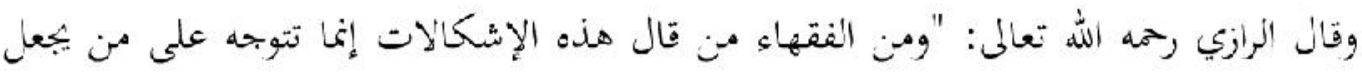

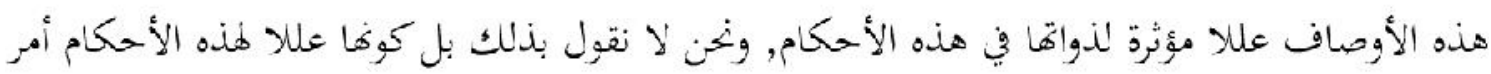

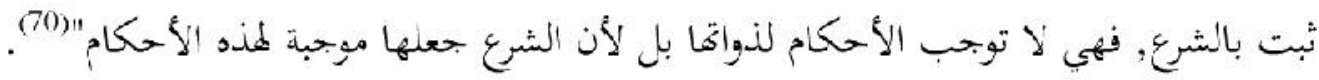

\section{مناقثة الأدلة وبيان الراجح}

بعد عرض زأي القاضي وزأي المخحالفين له, وبيان أدلة كل منهم في هذه المسألة, يترجح لدي أن

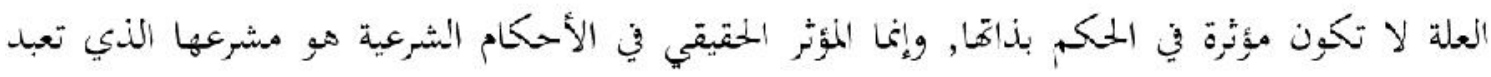

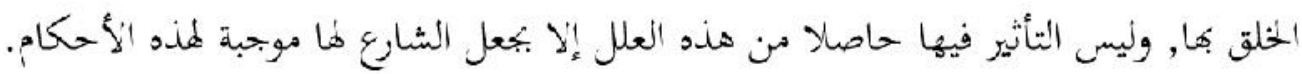

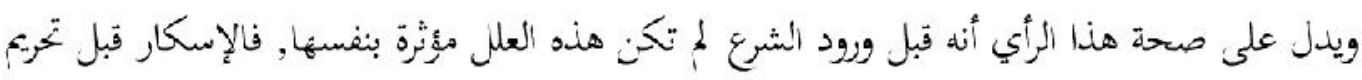

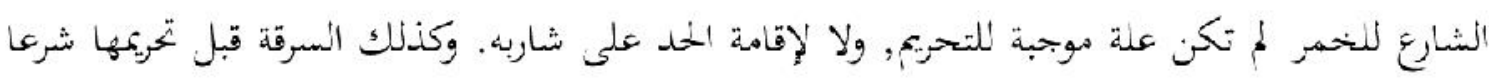

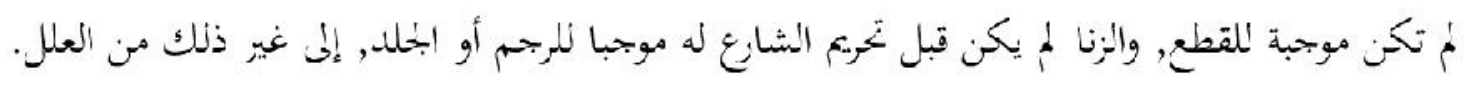

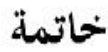

وبما أن البحث بلغ ثهايته, فإنه من المناسب أن أبرز أهم النتائج التي توصلت إليها, وتتلخص

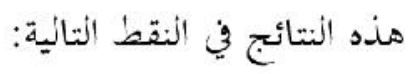
رأى القاضي عبد الجبار أن القياس حجة شرعية, ووانقه على هذا الرأي جمهور الأصوليين. وهو

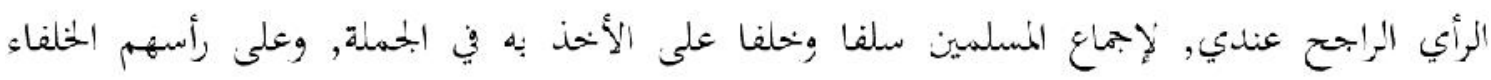

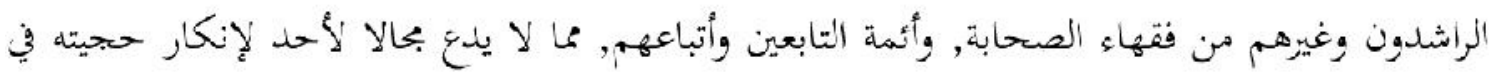
بناء الأحكام الشرعية.

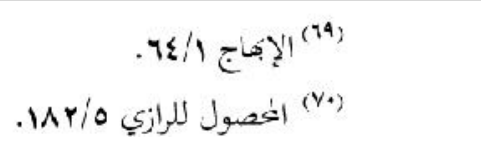


القاضي عبد الجبار المعتزلي وآراءه في القياس:M. Amar Adly

ورأى القاضي عبد الجبار أن القياس يوصف بالدين, أو هن الدين, أو يسمى دينا, ووافقه على هذا الرأي جهور الأصوليين. وهو الراجح لورود الأمر الثرعي بائتعبد به, وانعقاد إجماع الأمة في الجمدلة بمقتضاه, وكل ها كان مأمورا به شرعا فهو من الدين. أما في مسألة تأثير العلة في الحكم بنغسها, بلغة أخرى أنها الموجب بألهم بذاتما في الأحكام فإن القاضي يرى أن العلة مؤثرة بنفسها في الحلكم. ويترجح لدي خحلاف رأيه وهو أن العلة لا تكون مؤثرة

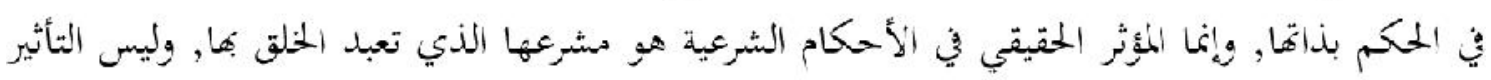

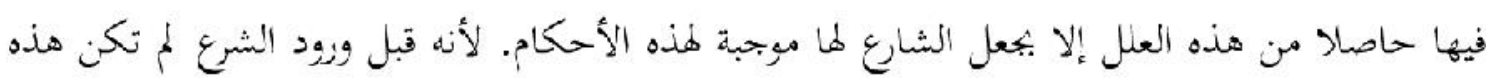

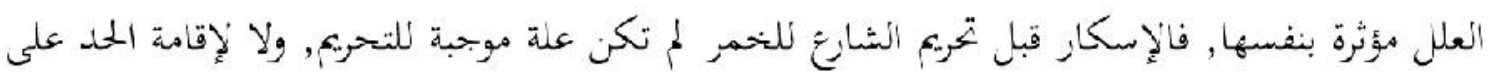

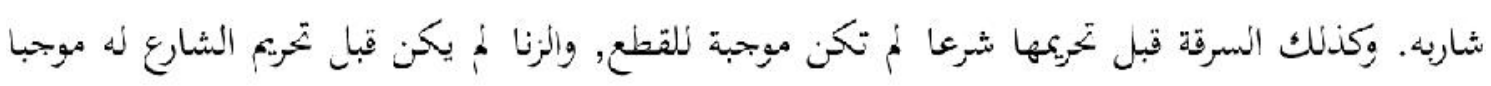
للرجم أو الجلد, إلى غير ذلك من العلى.

\section{المصادر}

ابن الأثير الجزري، الكامل في الثناريخ, الطبعة الأولى سنة ا+باه، بالمطبعة الأزهرية.

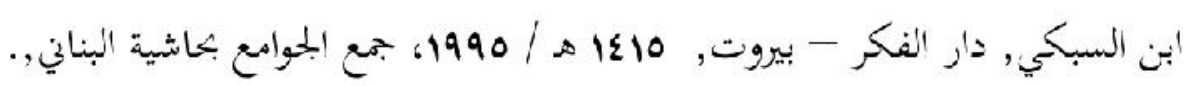

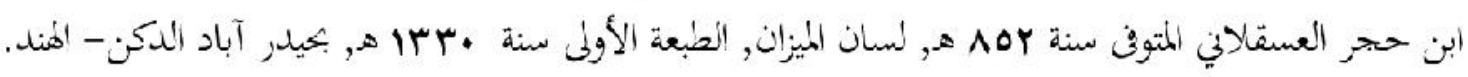

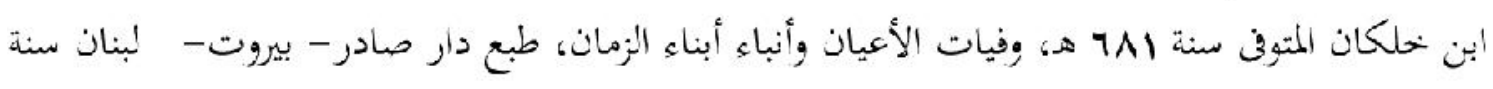

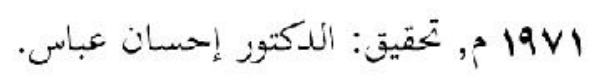

ابن قدامة المقدسي المتوفن سنة البه هـ, المغني, طبع مكتبة الرباض الحمديثة سنة ا+عاء هـ.

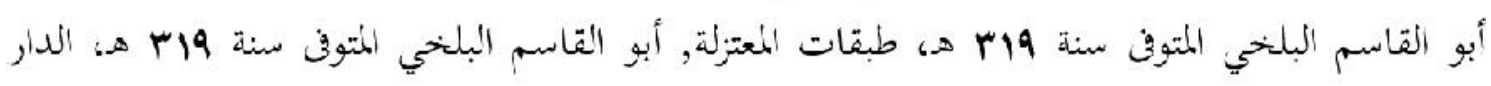

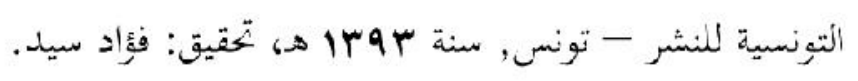

أبو التقاسم البلنتي, والتقاضي عبد الجبار, والحساكم الجشدي, فضل الاعتزلل وطبقات المعتزلة, الدار انتونيسية للنشر سنة سوبا هـ, تحقيق: فئاد سعيل.

أبو حيان التوحيدي, كتاب الأمناع والمؤانسة, القاهرة, سنة وله 19 م, تحقيق: أحمد أمين وأحمد الزين. أبو زكريا يهيى بن شرف بن هري النوبي, ( ابT-7VT هـ), صحيح مسلم بشرح النووي, دار إحياء

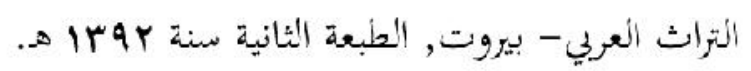
أبو زكريا يهيى بن شرف بن مري النووي, صحيح مسلم بشرح النووي, طبع دار الفكر - بيروت, سنة 1عا1 هـ، نشر وتوزيع إدارة البحوث العلمية والإفتاء بالمُملكة العربية السعودية. 
MIQOT Vol. XXXVIII No. 2 Juli-Desember 2014

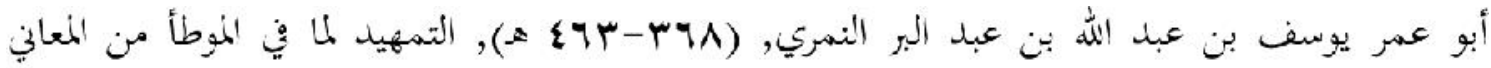

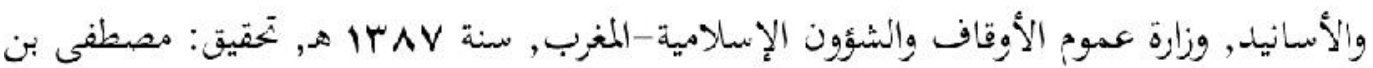

$$
\text { أحمد العلوي, محمد عبد الكبير البكري. }
$$

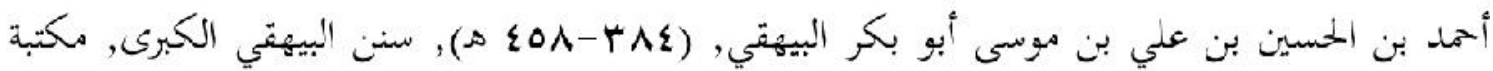

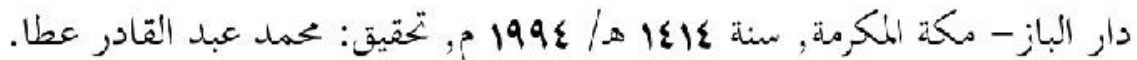
أحمد بن محمد بن إسحاق الشاشي أبو علي, المتّرفى سنة عـب هر, أصول الثاشي, دار الكتاب العربي بيروت, هـ

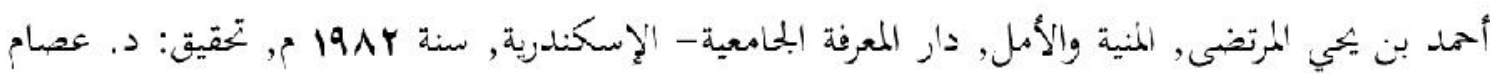
الدين خمد علي.

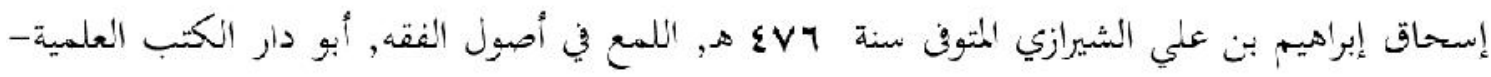

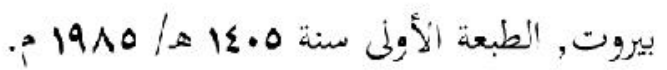

بن علي بن حجر أبو الفضل العسقلاذي الشافعي, (1) (AOY-VYY), لسان الميزان, أحمد مؤسسة الأعلمي

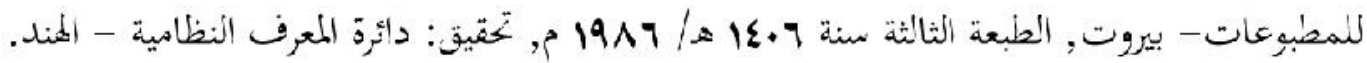
الحمافظ أبو بكر الخططيب البغدادي, المتوفي سنة جع هـ، تاريخ بغداد, نشر دار المكتاب العربي - بيروت. خليل بن كيكلدي العلاتي(ع الإسلامي- الكويت, الطبعة الأولف سنة V+عا ه, تحقيق: د. محمد سليمان الأشقر.

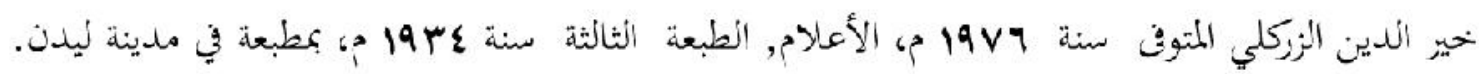

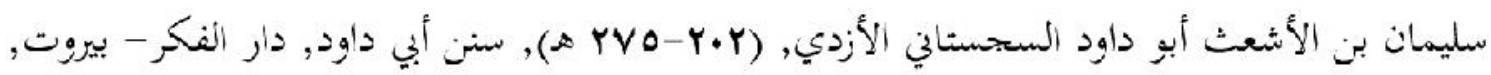
تحقيق: محمد محيي الدين عبد الحميد.

شمس الدين الذهبي المتوفن سنة V\& هـ سير أعلام الثباله, تحقيق: صلاح الدين المحد، حار المعارف -

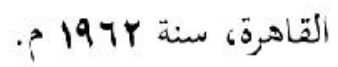

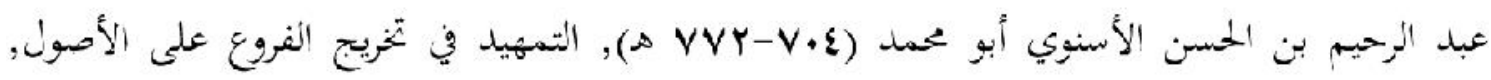
مؤسسة الرسالة - بيروت, الطبعة الأولى سنة ..عا هـ, تحقيق: د. محمد حسن هيتو.

علي بن عبد الكافي السبكي المثتف سنة V0Y هـ الإنماج في شرح المنهاج على هنهاج الوصول إلى علم الأصبل للبيضاوي, دار الكتب العنمية - بيروت, الطبعة الأولى سنة ع.كا هـ, تحقيق: جماعة من العنماء. علي بن محمد البزدوي الحنفيى, المتوفن سنة بیى هـ, أصول البزدوي المسمى بكنز الوصولا إلى معرفة الأصون, مطبعة جاويد بريس - كراتشي. 
القاضي عبد الجبار المعتزلي وآراءه في القياس:M. Amar Adly

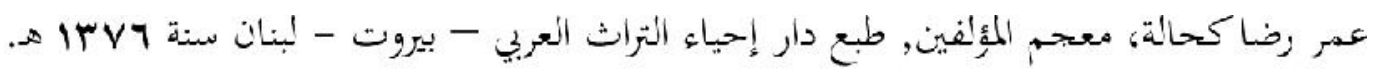

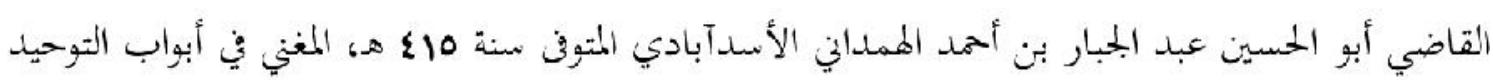
والعدلد, وزارة الثقافة والإرشاد القومي - المؤسسة المصبرية العامة، تحير: أمين الخولي، وإنشراف: دكتوز طه حسين.

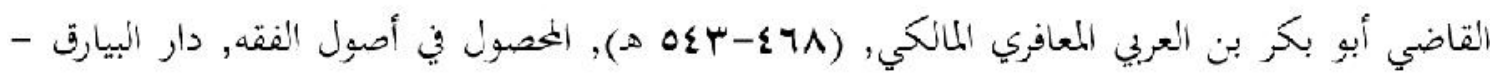
الأردن, الطبعة الأولى سنة •rأ1 هـ/ 1999 م, تحقيق: حسين علي اليدري.

بمسع الملك فهد اطباعة المصحف الشريف، المصحف الشريف, برواية حفص عن عاصم, طبع بالملدينة

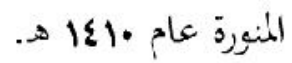
محمد بن أحمد بن أبي سهل السرخسي أبو بكر موعـ هـ، أصول السرخسي,. محمد بن إسحاق بن خزيمة أبو بكر المسفمي النيسابوري, (rYY-YII هـ), صحيح ابن خحزيمة, المكتب الإسلاني- بيروت, سنة •9 با ه/ • 19V م, تحقيق: د. محمل مصطفى الأعظمي.

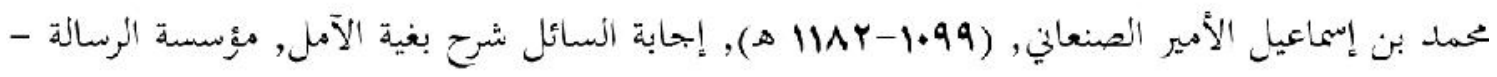

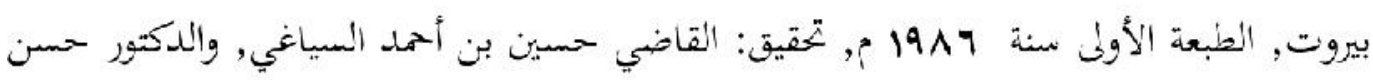

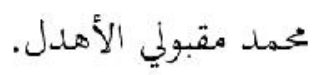
محمد بن علي بن الطيب البصري أبو الحسين, المتوفن سنة بسع هـ, المعتمد في أصول الفقه, دار الكتب

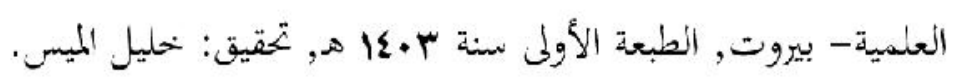

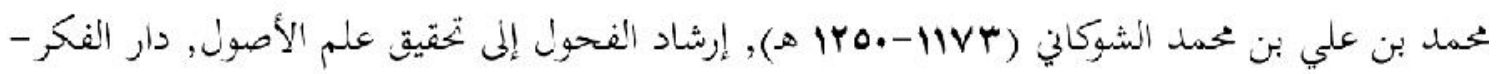
بيروت, النطبعة الأولى سنة باعا هـ/ 1994 م, تحقيق: محمد سعيد البدري أبو مصعب.

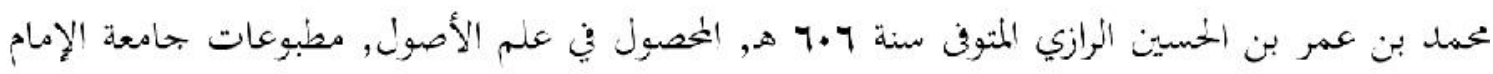

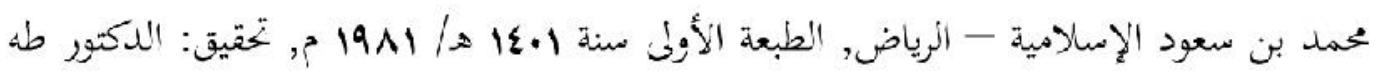
جابر فياض العلواني.

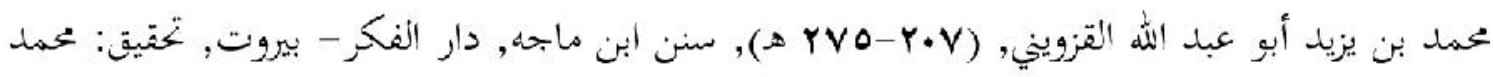
فؤاد عبد الباتي. محمد شمس المق العظيم آبادي أبو الطيب, عون المعبود شرح سنن أبي داود, محمد شمس المق العظيم آبادي أبو الطيب, دار الكتب العلمية - بيروت, الطبعة الثانية سنة 10عا هـ. 